\title{
Effect of Salt Reduction on Consumer Acceptance and Sensory Quality of Food
}

\author{
Ulla Hoppu ${ }^{1}$, Anu Hopia ${ }^{1}$, Terhi Pohjanheimo ${ }^{1}$, Minna Rotola-Pukkila ${ }^{1}$, Sari Mäkinen ${ }^{2}$, \\ Anne Pihlanto ${ }^{2}$ and Mari Sandell ${ }^{1, *}$ \\ 1 Functional Foods Forum, University of Turku, 20014 Turku, Finland; ulla.hoppu@utu.fi (U.H.); \\ anu.hopia@utu.fi (A.H.); terhi.pohjanheimo@utu.fi (T.P.); minna.rotola-pukkila@utu.fi (M.R.-P.) \\ 2 Natural Resources Institute Finland (LUKE), 31600 Jokioinen, Finland; sari.makinen@luke.fi (S.M.); \\ anne.pihlanto@luke.fi (A.P.) \\ * Correspondence: mari.sandell@utu.fi; Tel.: +358-40-3524149
}

Received: 30 October 2017; Accepted: 23 November 2017; Published: 27 November 2017

\begin{abstract}
Reducing salt $(\mathrm{NaCl})$ intake is an important public health target. The food industry and catering services are searching for means to reduce the salt content in their products. This review focuses on options for salt reduction in foods and the sensory evaluation of salt-reduced foods. Simple salt reduction, mineral salts and flavor enhancers/modifiers (e.g., umami compounds) are common options for salt reduction. In addition, the modification of food texture and odor-taste interactions may contribute to enhanced salty taste perception. Maintaining consumer acceptance of the products is a challenge, and recent examples of the consumer perception of salt-reduced foods are presented.
\end{abstract}

Keywords: salt; reduction; food; taste; consumer; sensory

\section{Introduction}

High dietary salt $(\mathrm{NaCl})$ intake is a significant risk factor for hypertension and thus a common public health challenge worldwide [1]. The World Health Organization recommends that adults should consume less than $2 \mathrm{~g}$ of sodium (5 $\mathrm{g}$ of salt) per day [2]. The current intake exceeds the recommended levels-for example, in selected European countries, the average salt intake of women is 7.3-10 g/day and that of men is 9.4-13.3 g/day [3]. The World Health Organization (WHO) global action plan for the prevention of non-communicable diseases aims to attain a 30\% reduction in the mean population intake of salt [4]. Many countries have initiated programs targeting salt reduction [5].

In many European countries, home cooking has been declining, and only a very small part of sodium intake comes from household salt intake [6]. Processed foods in general (e.g., bread and bakery products, processed meat products, and cheese) contribute markedly to sodium intake [7]. Ready meals may have high salt levels [8], and currently, people eat more frequently outside the home (e.g., restaurants, fast-food outlets, and workplace canteens), where the salt content of meals may also be high [9]. Thus, for an ordinary consumer, reducing salt intake is a challenge because the choice of low-salt options in the market may be limited. Therefore, the role of the food industry and food services is critical, but they may have fears regarding reduced consumer preference and thus sales of low-salt products. In addition to taste, salt also contributes to other sensory characteristics, such as the aroma profile of foods, by increasing the volatility of aroma compounds, or mouthfeel, by affecting the lubricating properties of saliva [10]. Having an effect, for example, on the water holding capacity of proteins and water activity, salt has an effect on technological characteristics such as texture and microbiological safety of foods $[11,12]$.

This review will focus on the perception of salty taste and the effects of salt reduction or modification of taste for the sensory perception of salty foods. Maintaining consumer preference 
is critical in developing low-salt products, and thus, the focus will be on the recent publications (mainly since 2010) on consumer acceptance and liking of salt-reduced/modified food products among adults.

\section{Salt Taste Perception and Taste Interactions}

\subsection{Taste Receptors}

Humans perceive five different taste modalities (bitter, sweet, umami, sour and salty). Taste receptors for bitter (TAS2R), as well as umami and sweet, are G-protein-coupled receptors [13]. During recent years, in particular, the perception of bitter taste has been studied actively, and the genetic variation in bitter taste receptors (e.g., TAS2R38) has been shown to be associated with individual differences in the sensitivity to specific bitter compounds and preference and consumption for certain foods, such as bitter-tasting vegetables [14,15].

Salt taste receptors have been studied much less, and the proposed receptor for salt taste is the epithelial sodium channel ENaC [16]. Genetic variation in the TRPV1 and SCNN1B genes has been suggested to modify salt taste perception in humans [17]. Heritability studies have suggested that genetics plays a smaller role in determining individual differences in the recognition thresholds for saltiness compared with those for sourness [18]. Recent findings have also suggested that multiple mechanisms could underlie the Amiloride-insensitive salt responses in type III taste cells [19], thus providing new insights into understanding the mechanisms underlying salt taste perception.

\subsection{Salt Taste Sensitivity and Preference}

Salt taste sensitivity and correlation to liking and intake also remains contradictory. In the USA, Hayes et al. [20] reported that females and males differed in their salt perception, and the impact of saltiness on liking varied across the food type. In Korea, men were found to have significantly higher thresholds and preferences for salty taste than women [21]. The salt detection threshold differed significantly between males and females, but individual salt detection and recognition thresholds had no significant effect on consumer acceptability and purchase intent scores of reduced-sodium vegetable soups [22]. Lucas et al. [23] found that the detection and recognition thresholds of $\mathrm{NaCl}$ were not associated with perceived saltiness, liking or intake of the food sample. Furthermore, the liking of salty foods differed in the sensory laboratory or dining room environment [23]. Therefore, it is not possible to predict the liking or consumption of salty foods based on a simple salt sensitivity test.

Whether the liking of specific culture-specific salty foods may be an indicator of salt intake remains also open. Among Japanese subjects, the self-reported preference for salt taste in miso soup was associated with daily sodium intake [24]. It is also debatable regarding how easy it is to adopt to a low-sodium diet in general, and the studies have conflicting findings that could be explained by different study populations, the duration of the diet, and the test samples, among other factors. In a controlled low-sodium diet, no effect of reduced salt exposure over weeks on salt taste responses was observed [25]. Furthermore, sodium supplementation as capsules for four weeks did not change the salt taste responses, suggesting that preference for saltiness is independent of bodily sodium levels [25]. The simple salt taste preference test ( $\mathrm{NaCl}$ in different concentrations in water solution) may have different results from actual salt level liking of complex foods and dishes as reviewed in later chapters.

\subsection{Flavor Interactions}

The studies focusing on single salt taste quality as evaluated in taste thresholds and preferences of $\mathrm{NaCl}$-water solutions in sensory laboratory may be misleading because, in foods, many different taste qualities are perceived simultaneously. When different taste qualities are mixed, several interactions (both enhancement and suppression) may occur, also depending on the food matrix [11]. Binary interactions have been studied in mixtures of aqueous solutions, and it has been 
shown that sour acids enhanced saltiness, and salts and sweeteners suppressed bitterness, as reviewed by Wilkie and Capaldi Phillips [26]. Therefore, if salt is reduced in food, other taste qualities, such as bitterness, may become more prevalent. Novel sensory evaluation techniques, such as the temporal dominance of sensations may provide new insights into multiple combinations of tastes [27].

In addition to the five primary taste qualities, the sensitivity to specific fatty acids and perception of fat may differ individually [28]. Fat and salt are a common combination in foods. The lipid content of a sample (oil-in-water emulsions) can affect saltiness perception [29]. Recently, Bolhuis et al. [30] reported that in tomato soups with different fat and salt contents, salt and fat affected pleasantness separately, with salt having the strongest effect.

\section{Salt Reduction in Food}

\subsection{Overview of Previous Reviews}

As salt reduction has been a topical issue, many thorough reviews have been published in recent years. Sodium reduction from a food industry perspective, in general, has been covered by some reviews [31,32]. Doyle and Glass [33], in turn, noted the safety issues (preservation and microbiological safety) in sodium reduction. Belz et al. [34], as well as Silow et al. [35], focused on salt reduction in bread and bakery products and dealt with both technological and qualitative challenges. Salt in bread from a European perspective was reviewed by Quilez and Salas-Salvado [36]. Sodium reduction in meat products has also been covered [37,38]. The review by Inguglia et al. [38] also listed some examples of commercially available products for sodium reduction for the food sector.

Jaenke et al. [39] conducted a systematic review and meta-analysis of salt-reduced foods, containing tables of previous studies on salt reduction or replacement (mainly $\mathrm{KCl}$ or soy sauce). According to Jaenke et al. [39], consumer acceptance may be maintained even after very significant reductions of the salt content, but the results may differ between product categories (e.g., bread, cheese, and meat products). From the perspective of flavor, Liem et al. 2011 [11] discussed the sensory role of sodium, taste interactions and reduction of sodium, considering palatability. Since 2011, many new articles have been published, some of which are outlined in the present review (Figure 1). focusing on the sensory evaluation and consumer preferences of salt-reduced foods.

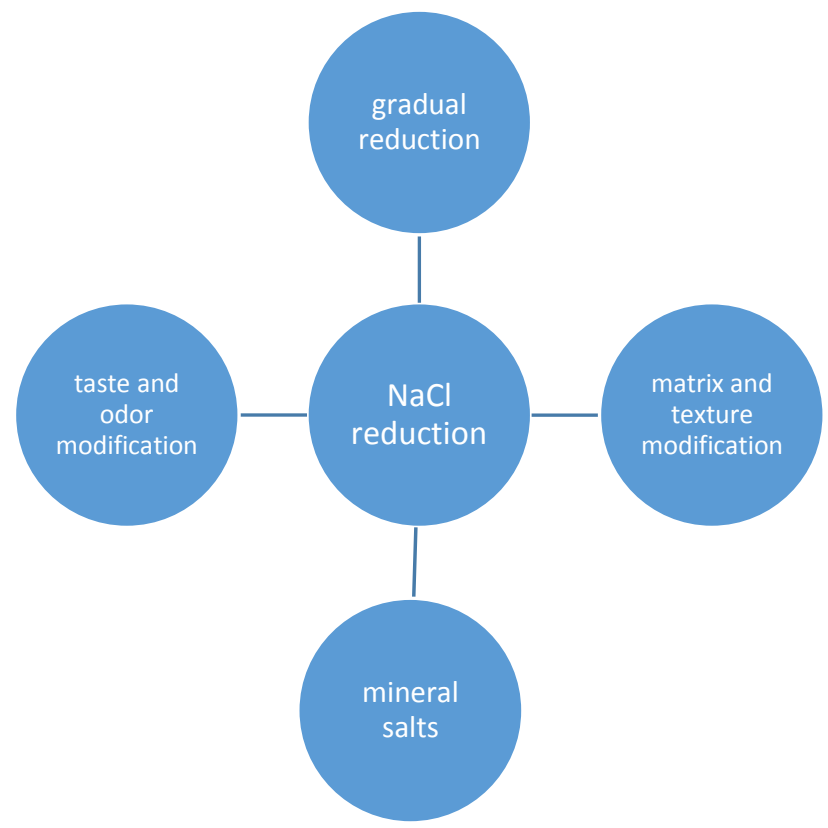

Figure 1. Overview of options for salt $(\mathrm{NaCl})$ reduction in foods covered in this review. 


\subsection{Simple Salt Reduction}

Few examples of recent studies concerning different options for salt reduction are reviewed here. The most obvious and simplest option is to reduce the salt content of the products. The levels of salt reduction between products, as well as study protocols in sensory laboratories or real-life conditions, have varied, and some examples are discussed here. A consumer panel in a sensory laboratory evaluated reduced-sodium cheddar and mozzarella cheeses, and it was found that consumers could distinguish a $30 \%$ salt reduction [40]. In meat products evaluated by a trained sensory panel, the sensory parameters most affected by the salt reduction were salty taste, juiciness and texture. In sausages and ham, moderate salt reduction did not have a significant effect on the sensory quality, while bacon and salami were significantly affected after a moderate reduction [41].

Consumer tests measured the ability to detect differences in reduced-sodium bread and control bread (two-alternative forced-choice testing), acceptability including overall liking (nine-point hedonic scale) and purchase intent, and it was found that reducing sodium levels by up to $30 \%$ in bread did not affect consumer liking or purchase intent of the product [42]. When subjects consumed a buffet-style breakfast on weekdays for four weeks and received either regular bread or bread with gradually lowered salt content, 50\% salt reduction in bread did not decrease bread consumption or affected the choice of sandwich fillings [43]. On the other hand, Antunez et al. [44] reported a large heterogeneity in consumer hedonic reactions to salt reduction in bread, and they noted the importance of consumer segmentation to understand consumer reactions to salt reduction.

In a 16-week longitudinal study, no overall difference in liking for low-sodium tomato juice at the final taste test was observed, but gradual salt reduction was more acceptable than the abrupt salt reduction [45]. Individual differences in hedonic sensitivity for salt and in the motivation to reduce salt intake may be challenging to reduce salt intake, and strategies targeted to specific consumer groups may be needed [45]. Multiple exposures have generally been shown to increase the liking of novel flavors and foods. The liking of soups varying in salt content has also been investigated, and it was shown that simple repeated exposure to the taste of the no-added salt soup was sufficient to increase liking [46].

\subsection{Mineral Salts}

A second option is to use mineral salts where sodium has been replaced by potassium, magnesium or calcium. However, the flavor characteristics of these salts may often be evaluated as negative by consumers. $\mathrm{KCl}$ may be associated with unpleasant side tastes such as bitter, metallic and chemical [47]. Individual variation in the perception of non-salty tastes for $\mathrm{KCl}$ was also observed to be large [47].

Therefore, regarding sensory properties, usually only a portion of $\mathrm{NaCl}$ may be replaced by other salts. For example, in reduced-fat mortadella, the sensory acceptance was best when $50 \% \mathrm{NaCl}$ was replaced by $25 \% \mathrm{KCl}$ and $25 \% \mathrm{CaCl}_{2}$; however, calcium chloride reduced the emulsion stability and cooking yield [48]. In dry-cured ham, all sensory attributes were affected, yielding poorer scores in the case of hams containing $\mathrm{CaCl}_{2}$ and $\mathrm{MgCl}_{2}$. Hams salted with $\mathrm{KCl}+\mathrm{NaCl}$ were rated equally to control hams, except for worse taste, probably due to the potassium contribution to a bitter taste [49].

In reduced-sodium cheddar-style cheese, both $\mathrm{CaCl}_{2}$ and $\mathrm{MgCl}_{2}$ produced considerable off-flavors (bitter, metallic, soapy), while cheeses containing $\mathrm{KCl}+\mathrm{NaCl}$ did not differ significantly from control, as evaluated by descriptive sensory analyses of a trained panel [50]. Some other flavoring extracts and compounds have been used in combination with $\mathrm{KCl}$ to improve the sensory attributes-for example, yeast extract [51].

\subsection{Umami Taste Compounds}

Umami taste is described as brothy or beefy, and the taste sensation comes from free amino acids glutamic acid (glutamate) and, to a lesser extent, aspartic acid [52]. Umami taste can be enhanced by the presence of free nucleotides such as inosine-5'-monophosphate (IMP), guanosine-5'-monophosphate 
(GMP) and adenosine-5'-monophosphate (AMP) [53]. Glutamate is one of the most abundant naturally occurring amino acids and free glutamic acid is found in many foods, such as meat and poultry, seafood, seaweed, cheese, fermented beans, tomato and mushrooms [54]. Several Asian foods-for example, soy sauce and fish sauce - are rich in umami compounds [55]. The cooking temperature and time may affect the concentration of umami compounds in pork meat [52].

Natural umami sources have been used in salt-reduced foods-for example, mushrooms in meat dishes [56]. Soy sauces contain salt, but it is also possible to reduce the salt content of a product by replacing $\mathrm{NaCl}$ with soy sauce, without lowering the total taste intensity and pleasantness [57]. Monosodium glutamate (MSG) is often used as a flavor enhancer in savory foods. The addition of MSG to spicy soups allowed the reduction of the sodium content without affecting the pleasantness, saltiness or taste intensity of the soups [58]. Calcium di-glutamate (CDG) may also improve the sensory and hedonic characteristics of lower sodium foods because it was found that CDG could partly replace sodium chloride in chicken broths [59].

\subsection{Modification of Food Matrix and Texture}

Food matrix and texture may have effects on sodium release and, thus, saltiness perception and may offer new options for salt reduction [60]. Product composition examples are the rate of dissolution from salt crystals via changing their size and shape, textural effects such as the hardness/brittleness of the food product and inhomogeneous distribution of salt to provide taste contrasts [61]. For example, using coarse-grained $\mathrm{NaCl}$ in bread significantly accelerated sodium release and led to enhanced salt taste and a sodium reduction in bread by $25 \%$ while maintaining taste [62]. Additionally, the late addition of coarse-grained $\mathrm{NaCl}$ to pizza dough was shown to enhance saltiness through taste contrast and accelerated sodium delivery in the mouth [63].

Modification of wheat bread texture resulted in a significantly faster sodium release from coarse-pored compared with fine-pored bread, thus enhancing saltiness perception [64]. Air inclusions within hydrogels were shown to increase both the delivery and perception of salt and aroma [65]. Interestingly, sandwiches containing regions of different salt levels were perceived significantly saltier than sandwiches containing the same overall salt content distributed homogeneously, suggesting that perceptual expectation based on the first bite can influence saltiness perception [66]. Heterogeneous salt distribution in hot-served layered snack foods was also observed to enhance saltiness perception [67].

\subsection{Odor-Taste Interactions}

Additionally, cross-modal odor-taste interactions could be applied in the context of sodium reduction in complex food systems. Nasri et al. [68] reported that the addition of sardine aroma to the salt-containing solution compensated for a decrease of $25 \%$ of the salt content. Higher levels of savory aroma were also shown to compensate for salt reduction in instant bouillons [69]. Lawrence et al. [70] investigated odor-induced saltiness enhancement in a solid model cheese and showed that salt-associated odors (e.g., comté cheese) could enhance saltiness perception.

On the other hand, in a cheese flavor model (varying aroma, $\mathrm{NaCl}$ and lactic acid levels), it was shown that the levels of the tastes could be manipulated only to a certain extent before the cheese flavor intensity was suppressed [71]. Furthermore, Linscott and Lim [72] reported that saltiness and umami enhanced chicken and soy sauce odor intensities, while odors did not enhance taste intensities. Therefore, odor-taste interactions are challenging and require further study.

\subsection{Herbs and Spices}

Herbs and spices are often recommended to use in salt reduction [73], but there are very few studies focusing on this issue from a sensory point of view. Wang et al. [74] reported that the amount of salt consumers added to soup was decreased when the perceived herb flavor increased. However, high levels of herbs decreased the overall liking of soups [74]. An herb and spice blend added to 
tomato soup was found to enhance the perception of salty taste of the low-salt soup, and repeated exposure to the soups with herbs and spices increased their overall liking [75].

\subsection{Flavor Peptides}

Food protein-derived peptides are, in addition to the nutritional properties, important factors for the taste of processed and unprocessed foods [76,77]. Depending on the structure, peptides can elicit salty, sweet, sour, bitter and umami taste modalities and/or induce flavor-enhancing effects, while some peptide structures are neutral in taste [76-78]. Flavor peptides are typically less than $3000 \mathrm{Da}$ in molecular weight, and the interaction in taste is enabled with polar groups, amino and carboxyl groups [76]. Various food protein-derived hydrolysates and peptides have shown salty and umami flavors-for example, proteins from beef, fish, chicken, soy and nuts have been used to produce peptides with umami and salty flavor [77-82]. Salty flavor is attributed to the presence of charged terminals and amino acid residues in the peptide structure. Thus, the zwitterionic nature of the peptide is more important for the salty flavor than for the general conformational features of the peptide.

Despite the potential of peptides for the modification of flavor, the utilization of flavor peptides for salt reduction in food products is not straightforward. The concentration of unique flavor peptide structures in food matrixes and protein hydrolysates is typically low. Thus, the targeted peptide structures with salty flavor should be concentrated effectively before application into food products. Feasible technological solutions are needed to enable the concentration. Additionally, the safety of the concentrated peptide fractions needs to be considered and evaluated before application into food products.

\subsection{Food Services}

The above salt reduction of single food items in the food market has been covered, but much less is known about the content of salt and efforts to reduce it in various food services. Workplace canteens, restaurants and fast-food outlets are offering various options for their customers, but the sodium content of many food items and meals seems too high $[83,84]$. Furthermore, the trends do not seem to be improving because, between 1997/1998 and 2009/2010 at leading fast-food restaurants in the USA, the sodium content of lunch/dinner menu items has increased by $23 \%$ [85]. Customers have been found to substantially underestimate the sodium content of meals in fast-food restaurants [86].

Few studies have focused on consumer acceptance of reduced-sodium foods in catering services. In an experimental real-life canteen study setting, the consumption of reduced-sodium lunches was well accepted by consumers and decreased daily sodium intake [87]. In the USA, reducing sodium in restaurant menu items showed that the majority of slight to moderate versions of sodium-reduced items were acceptable to consumers [88]. A questionnaire study on consumer attitudes and meal satisfaction concerning sodium-reduced meals at worksite cafeterias suggested that improving the taste and diversifying the menus could lead the consumers to choose sodium-reduced meals [89].

Customers reported to be willing to see information on the salt content of the menu items in catering services [90] and that could assist consumers to make healthy choices. Restaurant owners and chefs seem to have mixed opinions. A survey among US take-out restaurant owners and chefs has indicated that most of them were willing and able to reduce the sodium content of their meals, but they also wanted to have training in food preparation and marketing of low-salt dishes [91]. On the other hand, food service chefs/managers in the UK and USA were found to be reluctant to reduce salt use and feared negative business outcomes along with salt reduction [92].

\subsection{Challenges in the Sensory Evaluation of Reduced-Salt Products}

As the previous examples have demonstrated, the sensory evaluation and consumer liking of salt-reduced products are a great challenge. As the results have been shown to be related to other sensory characteristics of the product, different salt reduction options may work in different products-for example, bread and meat products [39]. Because the salt content may also affect, 
for example, texture characteristics and color [35], the evaluation of salty taste intensity is usually not sufficient, but other sensory characteristics must be included.

Considering the practical aspects of sensory evaluation, the use of a trained panel or consumer tests should be carefully planned. Trained panels can evaluate small differences in sensory quality and are needed in the initial phase of screening salt reduction options. However, consumer evaluations and preferences are important to obtain an overview of the market potential. A useful approach is to apply both a trained panel and consumers together. Different consumer groups should be represented in the tests-for example, gender, age, and smoking may be associated with salty food preferences [93]. The challenge currently is that consumers have so many different lifestyle variables, values, attitudes, and motives, characteristics that might affect their food and product preferences [94,95].

The results obtained in the sensory laboratory may also differ from those obtained under real tasting conditions, such as home experiments. Romagny et al. [96] employed different methodologies and combined home and laboratory evaluations of pleasantness and willingness to pay to evaluate the impact of reducing fat, salt and sugar in commercial food products. They found that, in most cases, the reformulated products maintained consumer acceptance. Willems et al. [97] studied repeated in-home consumption on the liking of reduced-salt soups (regular-salt soup compared with $22 \%$ and $32 \%$ salt-reduced soups) and found no difference in liking the soups when consumed at home (twice weekly for five weeks). Furthermore, the initial liking was not predictive of liking after repeating the in-home period.

Herbert et al. [98] introduced a new method to quantify memory for the sensory characteristics of a recently consumed food. They found that most people recalled a reduced-salt soup as having a higher salt concentration and suggested that remembered saltiness is influenced by representations of ideal saltiness. They concluded that salt concentrations could be reduced to a greater extent than might be predicted by a direct comparison between a regular and a reduced-salt product [98]

\section{Conclusions}

Along with the public health targets and responsibility demands, it is clear that the food industry, restaurants and catering services should provide more low-salt options for consumers. Reducing salt is a challenge for food development because, besides flavor, issues such as texture and microbial safety must be targeted. The food industry and researchers often have a technological starting point to new innovations, but many consumers may have critical views toward, for example, new food additives [99]. Currently, many consumers prefer natural ingredients [100]. Thus, consumer perceptions on the acceptability of new salt taste replacers/modifiers should be evaluated well in advance in the development process.

With the vast supply of products in the market, it may be difficult to find low-salt products and, for many consumers, understanding the package markings and nutrient content information in food labels may be challenging. Therefore, clear labeling of lower salt products would be necessary. However, health labeling may have a negative effect on taste perception [101]. This finding indicates that consumer preferences of packaging and labeling options are also important to study.

Additionally, actions targeting consumer attitudes and knowledge on salt reduction are needed. The general population may not be aware of the salt intake recommendations and salt content of foods, and may not be interested in salt reduction [102]. Not even hypertension patients are aware or reach sodium targets [103]. Additionally, other healthy dietary habits are important for cardiovascular health [104].

In conclusion, many new options for products with a lower sodium content are available. However, evaluating consumer preferences of reduced salt products are of crucial importance for their market success. Raising consumer awareness of the need to reduce salt intake through social marketing and promotion of healthy food options in schools, workplaces, and other communities is important. A close collaboration between experts in food chemistry, food technology, sensory science, 
nutrition, and consumer science, as well as practical experts in the food industry and food services, is needed to cover consumer expectations of high-quality, healthy and good-tasting products.

Acknowledgments: We thank the Finnish Funding Agency for Innovation (TEKES) for funding the project "Value added compounds from food industry by-products" together with Finnish food companies, the University of Turku and the Natural Resources Institute Finland.

Author Contributions: U.H. and M.S. drafted the first version of the manuscript and all authors contributed to the content and writing, especially A.H., T.P. and M.R.-P. to sensory evaluation aspects and S.M. and A.P. to flavor peptides. All authors contributed to revision of the manuscript and have approved the final version.

Conflicts of Interest: The authors declare no conflict of interest.

\section{References}

1. Aburto, N.J.; Ziolkovska, A.; Hooper, L.; Elliott, P.; Cappuccio, F.P.; Meerpoh, J.J. Effect of lower sodium intake on health: Systematic review and meta-analyses. BMJ 2013, 346, f1326. [CrossRef] [PubMed]

2. World Health Organization (WHO). Guideline: Sodium Intake for Adults and Children; World Health Organization: Geneva, Switzerland, 2012.

3. Hendriksen, M.A.; van Raaij, J.M.; Geleijnse, J.M.; Breda, J.; Boshuizen, H.C. Health gain by salt reduction in Europe: A modelling study. PLoS ONE 2015, 10, e0118873. [CrossRef] [PubMed]

4. World Health Organization (WHO). Global Action Plan for the Prevention and Control of Noncommunicable Diseases 2013-2020; World Health Organization: Geneva, Switzerland, 2013.

5. Trieu, K.; Neal, B.; Hawkes, C.; Dunford, E.; Campbell, N.; Rodriguez-Fernandez, R.; Legetic, B.; McLaren, L.; Barberio, A.; Webster, J. Salt reduction initiatives around the world-A systematic review of progress towards the global target. PLoS ONE 2015, 10, e0130247. [CrossRef] [PubMed]

6. Andersen, L.; Rasmussen, L.B.; Larsen, E.H.; Jakobsen, J. Intake of household salt in a Danish population. Eur. J. Clin. Nutr. 2009, 63, 598-604. [CrossRef] [PubMed]

7. Ni Mhurchu, C.; Capelin, C.; Dunford, E.K.; Webster, J.L.; Neal, B.C.; Jebb, S.A. Sodium content of processed foods in the United Kingdom: Analysis of 44,000 foods purchased by 21,000 households. Am. J. Clin. Nutr. 2011, 93, 594-600. [CrossRef] [PubMed]

8. Kanzler, S.; Hartmann, C.; Gruber, A.; Lammer, G.; Wagner, K.H. Salt as a public health challenge in continental European convenience and ready meals. Public Health Nutr. 2014, 17, 2459-2466. [CrossRef] [PubMed]

9. Rasmussen, L.B.; Lassen, A.D.; Hansen, K.; Knuthsen, P.; Saxholt, E.; Fagt, S. Salt content in canteen and fast food meals in Denmark. Food Nutr. Res. 2010, 54, 2100. [CrossRef] [PubMed]

10. Koliandris, A.L.; Morris, C.; Hewson, L.; Hort, J.; Taylor, A.J.; Wolf, B. Correlation between saltiness perception and shear flow behaviour for viscous solutions. Food Hydrocoll. 2010, 24, 792-799. [CrossRef]

11. Liem, D.G.; Miremadi, F.; Keast, R.S. Reducing sodium in foods: The effect on flavor. Nutrients 2011, 3, 694-711. [CrossRef] [PubMed]

12. Taormina, P.J. Implications of salt and sodium reduction on microbial food safety. Crit. Rev. Food Sci. Nutr. 2010, 50, 209-227. [CrossRef] [PubMed]

13. Hayes, J.E.; Feeney, E.; Allen, A. Do polymorphisms in chemosensory genes matter for human ingestive behavior? Food Qual. Prefer. 2013, 30, 202-216. [CrossRef] [PubMed]

14. Sandell, M.A.; Breslin, P.A. Variability in a taste-receptor gene determines whether we taste toxins in food. Curr. Biol. 2006, 16, R792-R794. [CrossRef] [PubMed]

15. Sandell, M.; Hoppu, U.; Mikkilä, V.; Mononen, N.; Kähönen, M.; Männistö, S.; Rönnemaa, T.; Viikari, J.; Lehtimäki, T.; Raitakari, O.T. Genetic variation in the hTAS2R38 taste receptor and food consumption among Finnish adults. Genes Nutr. 2014, 9, 433. [CrossRef] [PubMed]

16. Roper, S.D. The taste of table salt. Pflugers Arch. 2015, 467, 457-463. [CrossRef] [PubMed]

17. Dias, A.G.; Rousseau, D.; Duizer, L.; Cockburn, M.; Chiu, W.; Nielsen, D.; El-Sohemy, A. Genetic variation in putative salt taste receptors and salt taste perception in humans. Chem. Senses 2013, 38, 137-145. [CrossRef] [PubMed]

18. Wise, P.M.; Hansen, J.L.; Reed, D.R.; Breslin, P.A. Twin study of the heritability of recognition thresholds for sour and salty taste. Chem. Senses 2007, 32, 749-754. [CrossRef] [PubMed] 
19. Lewandowski, B.C.; Sukumaran, S.K.; Margolskee, R.F.; Bachmanov, A.A. Amiloride-insensitive salt taste is mediated by two populations of type III taste cells with distinct transduction mechanisms. J. Neurosci. 2016, 36, 1942-1953. [CrossRef] [PubMed]

20. Hayes, J.E.; Sullivan, B.S.; Duffy, V.B. Explaining variability in sodium intake through oral sensory phenotype, salt sensation and liking. Physiol. Behav. 2010, 100, 369-380. [CrossRef] [PubMed]

21. Noh, H.; Paik, H.Y.; Kim, J.; Chung, J. Salty taste acuity is affected by the joint action of $\alpha$ ENaC A663T gene polymorphism and available zinc intake in young women. Nutrients 2013, 5, 4950-4963. [CrossRef] [PubMed]

22. Mitchell, M.; Brunton, N.P.; Wilkinson, M.G. The influence of salt taste threshold on acceptability and purchase intent of reformulated reduced sodium vegetable soups. Food Qual. Prefer. 2013, 28, 356-360. [CrossRef]

23. Lucas, L.; Riddell, L.; Liem, G.; Whitelock, S.; Keast, R. The influence of sodium on liking and consumption of salty food. J. Food Sci. 2011, 76, S72-S76. [CrossRef] [PubMed]

24. Takachi, R.; Ishihara, J.; Iwasaki, M.; Ishii, Y.; Tsugane, S. Self-reported taste preference can be a proxy for daily sodium intake in middle-aged Japanese adults. J. Acad. Nutr. Diet. 2014, 114, 781-787. [CrossRef] [PubMed]

25. Bolhuis, D.P.; Gijsbers, L.; de Jager, I.; Geleijnse, J.M.; de Graaf, K. Encapsulated sodium supplementation of 4 weeks does not alter salt taste preferences in a controlled low sodium and low potassium diet. Food Qual. Prefer. 2015, 46, 58-65. [CrossRef]

26. Wilkie, L.M.; Capaldi Phillips, E.D. Heterogeneous binary interactions of taste primaries: Perceptual outcomes, physiology, and future directions. Neurosci. Biobehav. Rev. 2014, 47, 70-86. [CrossRef] [PubMed]

27. Kawasaki, H.; Sekizaki, Y.; Hirota, M.; Sekine-Hayakawa, Y.; Nonaka, M. Analysis of binary taste-taste interactions of MSG, lactic acid and $\mathrm{NaCl}$ by temporal dominance of sensations. Food Qual. Prefer. 2016, 52, 1-10. [CrossRef]

28. Running, C.A.; Craig, B.A.; Mattes, R.D. Oleogustus: The unique taste of fat. Chem. Senses 2015, 40, 507-516. [CrossRef] [PubMed]

29. Suzuki, A.H.; Zhong, H.; Lee, J.; Martini, S. Effect of lipid content on saltiness perception: A psychophysical study. J. Sens. Stud. 2014, 29, 404-412. [CrossRef]

30. Bolhuis, D.P.; Newman, L.P.; Keast, R.S. Effects of salt and fat combinations on taste preference and perception. Chem. Senses 2016, 41, 189-195. [CrossRef] [PubMed]

31. Dötsch, M.; Busch, J.; Batenburg, M.; Liem, G.; Tareilus, E.; Mueller, R.; Meijer, G. Strategies to reduce sodium consumption: A food industry perspective. Crit. Rev. Food Sci. Nutr. 2009, 49, 841-851. [CrossRef] [PubMed]

32. Fouladkhah, A.; Berlin, D.; Bruntz, D. High-sodium processed foods: Public health burden and sodium reduction strategies for industry practitioners. Food Rev. Int. 2015, 31, 341-354. [CrossRef]

33. Doyle, M.E.; Glass, K.A. Sodium reduction and its effect on food safety, food quality and human health. Compr. Rev. Food Sci. Food Saf. 2010, 9, 44-56. [CrossRef]

34. Belz, M.C.; Ryan, L.A.; Arendt, E.K. The impact of salt reduction in bread: A review. Crit. Rev. Food Sci. Nutr. 2012, 52, 514-524. [CrossRef] [PubMed]

35. Silow, C.; Axel, C.; Zannini, E.; Arendt, E.K. Current status of salt reduction in bread and bakery products-A review. J. Cereal Sci. 2016, 72, 135-145. [CrossRef]

36. Quilez, J.; Salas-Salvado, J. Salt in bread in Europe: Potential benefits of reduction. Nutr. Rev. 2012, 70, 666-678. [CrossRef] [PubMed]

37. Verma, A.K.; Banerjee, R. Low-sodium meat products: Retaining salty taste for sweet health. Crit. Rev. Food Sci. Nutr. 2012, 52, 72-84. [CrossRef] [PubMed]

38. Inguglia, E.S.; Zhang, Z.; Tiwari, B.K.; Kerry, J.P.; Burgess, C.M. Salt reduction strategies in processed meat products-A review. Trends Food Sci. Technol. 2017, 59, 70-78. [CrossRef]

39. Jaenke, R.; Barzi, F.; McMahon, E.; Webster, J.; Brimblecombe, J. Consumer acceptance of reformulated food products: A systematic review and meta-analysis of salt-reduced foods. Crit. Rev. Food Sci. Nutr. 2017, 57, 3357-3372. [CrossRef] [PubMed]

40. Ganesan, B.; Brown, K.; Irish, D.A.; Brothersen, C.; McMahon, D.J. Manufacture and sensory analysis of reduced- and low-sodium Cheddar and Mozzarella cheeses. J. Dairy Sci. 2014, 97, 1970-1982. [CrossRef] [PubMed] 
41. Aaslyng, M.D.; Vestergaard, C.; Koch, A.G. The effect of salt reduction on sensory quality and microbial growth in hotdog sausages, bacon, ham and salami. Meat Sci. 2014, 96, 47-55. [CrossRef] [PubMed]

42. La Croix, K.W.; Fiala, S.C.; Colonna, A.E.; Durham, C.A.; Morrissey, M.T.; Drum, D.K.; Kohn, M.A. Consumer detection and acceptability of reduced-sodium bread. Public Health Nutr. 2015, 18, 1412-1418. [CrossRef] [PubMed]

43. Bolhuis, D.P.; Temme, E.H.; Koeman, F.T.; Noort, M.W.; Kremer, S.; Janssen, A.M. A salt reduction of 50\% in bread does not decrease bread consumption or increase sodium intake by the choice of sandwich fillings. J. Nutr. 2011, 141, 2249-2255. [CrossRef] [PubMed]

44. Antunez, L.; Gimenez, A.; Ares, G. A consumer-based approach to salt reduction: Case study with bread. Food Res. Int. 2016, 90, 66-72. [CrossRef]

45. Bobowski, N.; Rendahl, A.; Vickers, Z. A longitudinal comparison of two salt reduction strategies: Acceptability of a low sodium food depends on the consumer. Food Qual. Prefer. 2015, 40, 270-278. [CrossRef]

46. Methven, L.; Langreney, E.; Prescott, J. Changes in liking for no added salt soup as a function of exposure. Food Qual. Prefer. 2012, 26, 135-140. [CrossRef]

47. Sinopoli, D.A.; Lawless, H.T. Taste properties of potassium chloride alone and in mixtures with sodium chloride using a check-all-that-apply method. J. Food Sci. 2012, 77, S319-S322. [CrossRef] [PubMed]

48. Horita, C.N.; Morgano, M.A.; Celeghini, R.M.; Pollonio, M.A. Physico-chemical and sensory properties of reduced-fat mortadella prepared with blends of calcium, magnesium and potassium chloride as partial substitutes for sodium chloride. Meat Sci. 2011, 89, 426-433. [CrossRef] [PubMed]

49. Armenteros, M.; Aristoy, M.C.; Barat, J.M.; Toldrá, F. Biochemical and sensory changes in dry-cured ham salted with partial replacements of $\mathrm{NaCl}$ by other chloride salts. Meat Sci. 2012, 90, 361-367. [CrossRef] [PubMed]

50. Grummer, J.; Karalus, M.; Zhang, K.; Vickers, Z.; Schoenfuss, T.C. Manufacture of reduced-sodium Cheddar-style cheese with mineral salt replacers. J. Dairy Sci. 2012, 95, 2830-2839. [CrossRef] [PubMed]

51. Campagnol, P.C.; dos Santos, B.A.; Wagner, R.; Terra, N.N.; Pollonio, M.A. The effect of yeast extract addition on quality of fermented sausages at low $\mathrm{NaCl}$ content. Meat Sci. 2011, 87, 290-298. [CrossRef] [PubMed]

52. Rotola-Pukkila, M.K.; Pihlajaviita, S.T.; Kaimainen, M.T.; Hopia, A.I. Concentration of umami compounds in pork meat and cooking juice with different cooking times and temperatures. J. Food Sci. 2015, 80, C2711-C2716. [CrossRef] [PubMed]

53. Mouritsen, O.G.; Khandelia, H. Molecular mechanism of the allosteric enhancement of the umami taste sensation. FEBS J. 2012, 279, 3112-3120. [CrossRef] [PubMed]

54. Jinap, S.; Hajeb, P. Glutamate. Its applications in food and contribution to health. Appetite 2010, 55, 1-10. [CrossRef] [PubMed]

55. Hajeb, P.; Jinap, S. Umami taste components and their sources in Asian foods. Crit. Rev. Food Sci. Nutr. 2015, 55, 778-791. [CrossRef] [PubMed]

56. Myrdal Miller, A.; Mills, K.; Wong, T.; Drescher, G.; Lee, S.M.; Sirimuangmoon, C.; Schaefer, S.; Langstaff, S.; Minor, B.; Guinard, J.X. Flavor-enhancing properties of mushrooms in meat-based dishes in which sodium has been reduced and meat has been partially substituted with mushrooms. J. Food Sci. 2014, 79, S1795-S1804. [CrossRef] [PubMed]

57. Kremer, S.; Mojet, J.; Shimojo, R. Salt reduction in foods using naturally brewed soy sauce. J. Food Sci. 2009, 74, S255-S262. [CrossRef] [PubMed]

58. Jinap, S.; Hajeb, P.; Karim, R.; Norliana, S.; Yibadatihan, S.; Abdul-Kadir, R. Reduction of sodium content in spicy soups using monosodium glutamate. Food Nutr. Res. 2016, 60, 30463. [CrossRef] [PubMed]

59. Carter, B.E.; Monsivais, P.; Drewnowski, A. The sensory optimum of chicken broths supplemented with calcium di-glutamate: A possibility for reducing sodium while maintaining taste. Food Qual. Prefer. 2011, 22, 699-703. [CrossRef]

60. Kuo, W.Y.; Lee, Y. Effect of food matrix on saltiness perception-implications for sodium reduction. Compr. Rev. Food Sci. Food Saf. 2014, 13, 906-923. [CrossRef]

61. Busch, J.L.; Yong, F.Y.; Goh, S.M. Sodium reduction: Optimizing product composition and structure towards increasing saltiness perception. Trends Food Sci. Technol. 2013, 29, 21-34. [CrossRef]

62. Konitzer, K.; Pflaum, T.; Oliveira, P.; Arendt, E.; Koehler, P.; Hofmann, T. Kinetics of sodium release from wheat bread crumb as affected by sodium distribution. J. Agric. Food Chem. 2013, 61, 10659-10669. [CrossRef] [PubMed] 
63. Mueller, E.; Koehler, P.; Scherf, K.A. Applicability of salt reduction strategies in pizza crust. Food Chem. 2016, 192, 1116-1123. [CrossRef] [PubMed]

64. Pflaum, T.; Konitzer, K.; Hofmann, T.; Koehler, P. Influence of texture on the perception of saltiness in wheat bread. J. Agric. Food Chem. 2013, 61, 10649-10658. [CrossRef] [PubMed]

65. Chiu, N.; Hewson, L.; Yang, N.; Linforth, R.; Fisk, I. Controlling salt and aroma perception through the inclusion of air fillers. Food Sci. Technol. 2015, 63, 65-70. [CrossRef]

66. Dijksterhuis, G.; Boucon, C.; Le Berre, E. Increasing saltiness perception through perceptual constancy created by expectation. Food Qual. Prefer. 2014, 34, 24-28. [CrossRef]

67. Emorine, M.; Septier, C.; Thomas-Danguin, T.; Salles, C. Heterogenous salt distribution in hot snacks enhances saltiness without loss of acceptability. Food Res. Int. 2013, 51, 641-647. [CrossRef]

68. Nasri, N.; Septier, C.; Beno, N.; Salles, C.; Thomas-Danguin, T. Enhancing salty taste through odour-taste-taste intercations: Influence of odour intensity and salty tastants' nature. Food Qual. Prefer. 2013, 28, 134-140. [CrossRef]

69. Batenburg, M.; van der Velden, R. Saltiness enhancement by savory aroma compounds. J. Food Sci. 2011, 76, S280-S288. [CrossRef] [PubMed]

70. Lawrence, G.; Salles, C.; Palicki, O.; Septier, C.; Busch, J.; Thomas-Danguin, T. Using cross-modal interactions to counterbalance salt reduction in solid foods. Int. Dairy J. 2011, 21, 103-110. [CrossRef]

71. Niimi, J.; Overington, A.R.; Silcock, P.; Bremer, P.J.; Delahunty, C.M. Cross-modal taste and aroma interactions: Cheese flavor perception and changes in flavor character in multicomponent mixtures. Food Qual. Prefer. 2016, 48, 70-80. [CrossRef]

72. Linscott, T.D.; Lim, J. Retronasal odor enhancement by salty and umami tastes. Food Qual. Prefer. 2016, 48, 1-10. [CrossRef]

73. Anderson, C.A.; Cobb, L.K.; Miller, E.R.; Woodward, M.; Hottenstein, A.; Chang, A.R.; Mongraw-Chaffin, M.; White, K.; Charleston, J.; Tanaka, T.; et al. Effects of a behavioral intervention that emphasizes spices and herbs on adherence to recommended sodium intake: Results of the SPICE randomized clinical trial. Am. J. Clin. Nutr. 2015, 102, 671-679. [CrossRef] [PubMed]

74. Wang, C.; Lee, Y.; Lee, S.Y. Consumer acceptance of model soup system with varying levels of herbs and salt. J. Food Sci. 2014, 79, S2098-S2106. [CrossRef] [PubMed]

75. Ghawi, S.K.; Rowland, I.; Methven, L. Enhancing consumer liking of low salt tomato soup over repeated exposure by herb and spice seasonings. Appetite 2014, 81, 20-29. [CrossRef] [PubMed]

76. Temussi, P.A. The good taste of peptides. J. Pept. Sci. 2012, 18, 73-82. [CrossRef] [PubMed]

77. Schindler, A.; Dunkel, A.; Stähler, F.; Backes, M.; Ley, J.; Meyerhof, W.; Hofmann, T. Discovery of salt taste enhancing arginyl dipeptides in protein digests and fermented fish sauces by means of a sensomics approach. J. Agric. Food Chem. 2011, 59, 12578-12588. [CrossRef] [PubMed]

78. Su, G.; Cui, C.; Zheng, L.; Yang, B.; Ren, J.; Zhao, M. Isolation and identification of two novel umami and umami-enhancing peptides from peanut hydrolysate by consecutive chromatography and Maldi-Tof/Tof MS. Food Chem. 2012, 135, 479-485. [CrossRef] [PubMed]

79. Zhang, M.X.; Wang, X.C.; Liu, Y.; Xu, X.L.; Zhou, G.H. Isolation and identification of flavour peptides from Puffer fish (Takifugu obscurus) muscle using an electronic tongue and MALDI-TOF/TOF MS/MS. Food Chem. 2012, 135, 1463-1470. [CrossRef] [PubMed]

80. Shen, Q.; Guo, R.; Dai, Z.; Zhang, Y. Investigation of enzymatic hydrolysis conditions on the properties of protein hydrolysate from fish muscle (Collichthys niveatus) and evaluation of its functional properties. J. Agric. Food Chem. 2012, 60, 5192-5198. [CrossRef] [PubMed]

81. Rhyu, M.R.; Kim, E.Y. Umami taste characteristics of water extract of Doejang, a Korean soybean paste: Low-molecular weight acidic peptides may be a possible clue to the taste. Food Chem. 2011, 127, 1210-1215. [CrossRef] [PubMed]

82. Lioe, H.N.; Takara, K.; Yasuda, M. Evaluation of peptide contribution to the intense umami taste of Japanese soy sauces. J. Food Sci. 2006, 71, 277-283. [CrossRef]

83. Brewster, L.M.; Berentzen, C.A.; van Montfrans, G.A. High salt meals in staff canteens of salt policy makers: Observational study. BMJ 2011, 343, d7352. [CrossRef] [PubMed]

84. Jaworowska, A.; Blackham, T.; Stevenson, L.; Davies, I.G. Determination of salt content in hot takeaway meals in the United Kingdom. Appetite 2012, 59, 517-522. [CrossRef] [PubMed] 
85. Rudelt, A.; French, S.; Harnack, L. Fourteen-year trends in sodium content of menu offerings at eight leading fast-food restaurants in the USA. Public Health Nutr. 2014, 17, 1682-1688. [CrossRef] [PubMed]

86. Moran, A.J.; Ramirez, M.; Block, J.P. Consumer underestimation of sodium in fast food restaurant meals: Results from a cross-sectional observational study. Appetite 2017, 113, 155-161. [CrossRef] [PubMed]

87. Janssen, A.M.; Kremer, S.; van Stipriaan, W.L.; Noort, M.W.; de Vries, J.H.; Temme, E.H. Reduced-sodium lunches are well-accepted by uninformed consumers over a 3-week period and result in decreased daily dietary sodium intakes: A randomized controlled trial. J. Acad. Nutr. Diet. 2015, 115, 1614-1625. [CrossRef] [PubMed]

88. Patel, A.A.; Lopez, N.V.; Lawless, H.T.; Njike, V.; Beleche, M.; Katz, D.L. Reducing calories, fat, saturated fat, and sodium in restaurant menu items: Effects on consumer acceptance. Obesity (Silver Spring) 2016, 24, 2497-2508. [CrossRef] [PubMed]

89. Lee, J.; Park, S. Consumer attitudes, barriers, and meal satisfaction associated with sodium-reduced meal intake at worksite cafeterias. Nutr. Res. Pract. 2015, 9, 644-649. [CrossRef] [PubMed]

90. Mackison, D.; Wrieden, W.L.; Anderson, A.S. Making an informed choice in the catering environment: What do consumers want to know? J. Hum. Nutr. Diet. 2009, 22, 567-573. [CrossRef] [PubMed]

91. Ma, G.X.; Shive, S.; Zhang, Y.; Aquilante, J.; Tan, Y.; Zhao, M.; Solomon, S.; Zhu, S.; Toubbeh, J.; Colby, L.; et al. Knowledge, perceptions, and behaviors related to salt use among Philadelphia Chinese take-out restaurant owners and chefs. Health Promot. Pract. 2014, 15, 638-645. [CrossRef] [PubMed]

92. Murray, D.W.; Hartwell, H.; Feldman, C.H.; Mahadevan, M. Salt, chefs and public health: An exploratory investigation of hospitality professionals. Br. Food J. 2015, 117, 1610-1618. [CrossRef]

93. Lampuré, A.; Schlich, P.; Deglaire, A.; Castetbon, K.; Péneau, S.; Hercberg, S.; Méjean, C. Sociodemographic, psychological, and lifestyle characteristics are associated with a liking for salty and sweet tastes in French adults. J. Nutr. 2015, 145, 587-594. [CrossRef] [PubMed]

94. Pohjanheimo, T.; Paasovaara, R.; Luomala, H.; Sandell, M. Food choice motives and bread liking of consumers embracing hedonistic and traditional values. Appetite 2010, 54, 170-180. [CrossRef] [PubMed]

95. De Boer, J.; Schösler, H. Food and value motivation: Linking consumer affinities to different types of food products. Appetite 2016, 103, 95-104. [CrossRef] [PubMed]

96. Romagny, S.; Ginon, E.; Salles, C. Impact of reducing fat, salt and sugar in commercial foods on consumer acceptability and willingness to pay in real tasting conditions: A home experiment. Food Qual. Prefer. 2017, 56 Pt A, 164-172. [CrossRef]

97. Willems, A.A.; van Hout, D.H.; Zijlstra, N.; Zandstra, E.H. Effects of salt labelling and repeated in-home consumption on long-term liking of reduced-salt soups. Public Health Nutr. 2014, 17, 1130-1137. [CrossRef] [PubMed]

98. Herbert, V.; Bertenshaw, E.J.; Zandstra, E.H.; Brunstrom, J.M. Memory processes in the development of reduced-salt foods. Appetite 2014, 83, 125-134. [CrossRef] [PubMed]

99. Bearth, A.; Cousin, M.E.; Siegrist, M. The consumer's perception of artificial food additives: Influences on acceptance, risk and benefit perceptions. Food Qual. Prefer. 2014, 38, 12-23. [CrossRef]

100. Hung, Y.; de Kok, T.M.; Verbeke, W. Consumer attitude and purchase intention towards processed meat products with natural compounds and a reduced level of nitrite. Meat Sci. 2016, 121, 119-126. [CrossRef] [PubMed]

101. Liem, D.G.; Miremadi, F.; Zandstra, E.H.; Keast, R.S. Health labelling can influence taste perception and use of table salt for reduced-sodium products. Public Health Nutr. 2012, 15, 2340-2347. [CrossRef] [PubMed]

102. Sarmugam, R.; Worsley, A. Current levels of salt knowledge: A review of the literature. Nutrients 2014, 6, 5534-5559. [CrossRef] [PubMed]

103. Ohta, Y.; Ohta, K.; Ishizuka, A.; Hayashi, S.; Kishida, M.; Iwashima, Y.; Yoshihara, F.; Nakamura, S.; Kawano, Y. Awareness of salt restriction and actual salt intake in hypertensive patients at a hypertension clinic and general clinic. Clin. Exp. Hypertens. 2015, 37, 172-175. [CrossRef] [PubMed]

104. Ndanuko, R.N.; Tapsell, L.C.; Charlton, K.E.; Neale, E.P.; Batterham, M.J. Dietary patterns and blood pressure in adults: A systematic review and meta-analysis of randomized controlled trials. Adv. Nutr. 2016, 7, 76-89. [CrossRef] [PubMed]

(C) 2017 by the authors. Licensee MDPI, Basel, Switzerland. This article is an open access article distributed under the terms and conditions of the Creative Commons Attribution (CC BY) license (http://creativecommons.org/licenses/by/4.0/). 